Homeownership and job-match quality in France

Carole Brunet, Nathalie Havet

Novembre 2011 


\section{GATE Groupe d'Analyse et de Théorie Économique Lyon-St Étienne}

93, chemin des Mouilles 69130 Ecully - France

Tel. +33 (0)4 72866060

Fax $+33(0) 472866090$

6, rue Basse des Rives 42023 Saint-Etienne cedex 02 - France

Tel. +33 (0)4 77421960

Fax. $+33(0) 477421950$

Messagerie électronique / Email : gate@gate.cnrs.fr

Téléchargement / Download : http://www.gate.cnrs.fr - Publications / Working Papers 


\title{
Homeownership and job-match quality in France
}

\author{
Carole Brunet* \\ LED \\ Université Paris 8
}

\author{
Nathalie Havet ${ }^{\dagger}$ \\ GATE Lyon-Saint Etienne \\ Université de Lyon, CNRS.
}

\begin{abstract}
Our empirical study stems from previous research on the inter-relations between residential status and microeconomic labour market outcomes. It focuses on employees and assesses the a priori ambiguous effect of homeownership on job-match quality. We use the French data set of the 1995-2001 European Community Household Panel to build a subjective measure of job downgrading. We estimate a recursive trivariate probit with partial observability that simultaneously models the residential status choice, its impact on the probability of being downgraded, and the selection into employment. The comparison with simpler models indicates that taking into account the selection into employment and controlling unobservable individual heterogeneity are of prime necessity to obtain robust conclusions.
\end{abstract}

Keywords : residential status, job downgrading, overeducation, job matching.

Mots clés : statut résidentiel, déqualification dans l'emploi, déclassement, appariement.

JEL: C35, J24, J28, R21

*LED, Université Paris 8. 2, rue de la Liberté 93526 SAINT-DENIS CEDEX. E-mail: carole.brunet@univparis8.fr

${ }^{\dagger}$ Université de Lyon, Lyon, F-69003, France ; Université Lyon 2, Lyon, F-69007, France ; CNRS, GATE Lyon St Etienne, Ecully, F-69130, France, 93, chemin des Mouilles B.P. 16769131 ECULLY. E-mail: havet@gate.cnrs.fr 


\section{Introduction}

During the last twenty years, homeownership has become more popular than home renting in OECD countries. Germany is an exception since the homeownership rate has remained less than $50 \%$ since the eighties. In other countries, homeownership rates have been increasing, especially in Belgium, Portugal, the United Kingdom, Spain and the Netherlands, displaying increases larger than 10\% in two decades [Catte, Girouard, Price \& André (2004, p.154)]. In most OECD countries, this evolution results from the implementation of different policies in favour of homeownership. France was no exception with several fiscal measures to promote primary residence ownership: soft loans, reductions in taxes on donations and inheritance and more recently the tax exemption on mortgage interests. Simultaneously the pro-cyclical behavior of banks contributed to this development with lower interest rates, longer loan maturity, lower down payment requirements and variable-rate loans.

Some papers have described evolutions of the housing market and housing prices along with the implementations of these policies. Others have adopted a more general analysis by studying the indirect effects of changes in residential status structure. Those studies cover several fields: economics, sociology, demography, education or political science ${ }^{1}$. Indeed, direct as well as indirect consequences of public policies which favour the creation of "nations of homeowners" must be assessed to gain insights about their relevance. However, such a statistical evaluation is delicate. Firstly, separating homeownership's effects from those of other characteristics is crucial but often difficult. The determinants of homeownership are numerous, including economic factors often unavailable in the empirical data, such as permanent income. Omitting a variable which influences both the likelihood of homeowning and the likelihood of engaging in a particular behaviour causes the estimated impact of homeownership on the outcome of interest to be biased. The coefficient of the homeownership variable also reflects unobserved individual characteristics, which are correlated with homeownership and omitted in the econometric specification. Secondly, the evaluation methods must take into account the bidirectional interactions between homeownership and its potential effects. For example, the home purchase and labour market decisions are often simultaneous: on the one hand, individuals with a good situation in the labour market are more likely to overcome mortgage lender constraints and also to be homeowner, and on the other hand, homeownership also influences labour market participation. Consequently, a robust econometric specification must deal with the potential endogeneity of the homeownership for the individual behaviours.

Our paper is related to the recent empirical literature on homeownership outcomes, which has evolved along with statistical methods handling these econometric issues. A large part of the research in this field focuses on the impact of homeownership on labour force behaviour ${ }^{2}$. The debate was initiated in the nineties by Oswald (1996, 1998, 1999). His starting point was the observation of a parallel evolution between increasing homeownership rate and the

\footnotetext{
${ }^{1}$ For a literature survey of all the micro-level consequences of homeownership, see for example Dietz \& Haurin (2003).

${ }^{2}$ For a literature survey, see Havet \& Penot (2010).
} 
unemployment rate. During the last decades, most European countries have indeed experienced strong increases both of the owner-occupation rate and of the unemployment rate. Oswald mainly relates this positive relationship to homeowners' mobility constraints, which would entail shorter employment durations, longer unemployment spells, as well as inadequate jobs for homeowners. Empirical literature has then concentrated on testing the two first aspects with econometric models. Recent studies, dealing with the appropriate treatment of unobserved heterogeneity and endogeneity problems, call into question the robustness and conclusions of early ones [Oswald (1996, 1998), Coulson \& Fisher (2002)]. For example, Munch, Rosholm \& Svarer (2006) for Denmark, van Vuuren (2009) for the Netherlands and Brunet, Havet \& Lesueur (2011) for France find that, other things being equal, homeowners have shorter unemployment duration than renters, while Battu, Ma \& Phimister (2008) and Brunet et al. (2011) conclude to no significant difference between these two groups in the United-Kingdom and the United States, respectively. Duration models including unobserved heterogeneity and dealing with the endogeneity issue have also been applied to the study of homeownership influence on professional mobility of employed individuals. Homeownership appears to generate individual benefits in terms of stability on the labour market in several European countries: de Graaff \& van Leuvensteijn (2007), de Graaff, van Leuvensteijn \& van Ewijk (2009), Munch, Rosholm \& Svarer (2008) and Battu et al. (2008) highlight that homeowners have longer employment durations than their renters counterparts. This is conveyed through both a $25 \%$ lower unemployment risk for homeowners, as well as $20 \%$ to $30 \%$ lower transition rates between jobs.

Overall, most recent studies highlight rather better labour market outcomes for homeowners, with reduced unemployment risks and also higher employment stability, which favour intra-firm career prospects. However, to our knowledge there has not been yet any evaluation of homeownership consequences with respect to job-match quality ${ }^{3}$, although some studies have highlighted the role of mobility in reducing job mismatch (see e.g. Hensen, de Vries \& Cörvers (2009)). Indeed, unemployed homeowners might have a faster exit rate out of unemployment because they are willing to lower their reservation wage and/or their job requirements in order to avoid relocation costs should a distant job offer be accepted. For those homeowners who still bear financial constraints, it might also be crucial to go back to employment quickly in order to face loan payments. Regarding the population in employment, residential status' influence on job-match quality is a priori ambiguous.

More precisely, human capital and spatial mobility theories predict opposite effects of homeowners' employment stability on job-match quality. On the one hand, by being more stable in employment, homeowners might acquire a higher level of specific human capital, which improves the adequacy of their qualifications to their occupation requirements and/or favour intra-firm promotions [Rosholm \& Svarer (2004), Munch et al. (2008)]. Therefore, higher employment stability of homeowners should be associated with superior job-match quality. Moreover, homeowners are more involved in their social environment and benefit from better "local" social networks in terms of job opportunities [David, Janiak \& Wasmer (2010)]. On

\footnotetext{
${ }^{3}$ For the basics of job matching theory, see Jovanovic (1979) and Johnson (1978).
} 
the other hand, homeowners value housing amenities and their family's stability, so that they might accept some degree of professional mismatch between their skills and qualifications and their job characteristics. Indeed, spatial mobility theories (see e.g. Simpson (1992) and Buchel \& van Ham (2003)) suggest that due to high mobility costs, homeowners are less prone to make a residential move in order to take on a new job which would be a better match. In a monopsonistic view of the labour market [see e.g. Boal \& Ransom (1997), Bhaskar, Manning \& To (2002)], employers might exploit mobility constraints of homeowners in order to set a discriminatory wage policy for a given education (and other productive factors) level, or alternatively to hire more productive (educated) workers for a given level of wages. Thus, the total effect of housing tenure on job-match quality has to be empirically assessed.

Following the well-known literature on overqualification, we use a job-downgrading measure as an indicator of job-match quality. In a broad sense, job-downgrading or overqualification ${ }^{4}$ corresponds to "a situation where individuals have higher qualifications that those which are usually required by the job they hold" [Hartog (2000), Fondeur (1999)]. Three main approaches have been used for downgrading evaluation in the empirical literature, albeit each has its own particular limitations [Hartog (2000), Sloane (2003), Nauze-Fichet \& Tomasini (2002, 2006)]. The normative approach is based on the qualification content required for a particular occupation, or conversely on the type of occupation a particular degree is specific to. Job downgrading is then measured as the difference between required education in the job and worker's education level. The main drawback of this approach lies in the construction of a correspondence grid between education levels and occupations, which is often debatable and more importantly, evolving. The statistical approach does not resort to some a priori established education level - occupation correspondence, but instead defines it on the basis of observed occurrences in the sample between workers education levels and the type of job they hold. Mismatch then occurs when a worker's level of education is more than one standard deviation above the mean level of education in her occupation. Again, this job downgrading measure requires a precise job as well as education levels classifications. Lastly, the subjective approach avoids these drawbacks by using a worker's self-assessment on the suitability of their qualifications or skills to her position. Following other authors (e.g. Alba-Ramirez \& Blázquez (2003), Budria \& Moro-Egido (2009)), we use such a measure based on individuals' statements about their job satisfaction.

Beyond labour market outcomes, our paper also complements studies of the impact of homeownership on household well-being. For example, Rossi \& Weber (1996) and Dietz \& Haurin (2003) suggest that homeownership increases household's life satisfaction, happiness and positive self-perception. Nevertheless, as pointed out by Dietz \& Haurin (2003), previous studies on homeownership and self-perception were flawed because of a limited number of control variables.

The remainder of the paper is organized as follows. We present our econometric methodology in section 2. The French data set of the 1995-2001 European Community Household

\footnotetext{
${ }^{4}$ In our paper, we will employ indifferently these two terms.
} 
Panel $(E C H P)$, which contains information on labour and housing markets is detailed in section 3 , and results are given in section 4. Issues arising from the results are summarized in section 5 .

\section{Econometric issues and modelling}

Our objective is to estimate the impact of the residential status on the job-match quality, which is measured by a dichotomous variable indicating whether the worker evaluates himself as job-downgraded or not.

Homeownership also depends on the job-match quality, which reflects job stability and expected earnings. Indeed, financial institutions grant mortgages under sufficient expected earning conditions for any home purchase. Moreover, a job-downgraded individual, being likely to try changing job in order to get a better match, might give up the idea of homeownership because he anticipates a future job mobility. We thus have to take into account the potential simultaneity between residential status and job downgrading. Since the homeownership variable is probably endogeneous in the job downgrading equation, we cannot evaluate the impact of homeownership on job downgrading by including a simple dichotomous variable equal to 1 if the individual is homeowner and 0 otherwise.

One approach for dealing with this endogeneity issue is to estimate a bivariate probit, which simultaneously models the probability to be a homeowner and the influence of homeownership on the probability to be downgraded. The chosen specification is recursive, i.e. we retain as preponderant explanatory variable of the job downgrading $\left(y_{i d}\right)$ the fact to be homeowner or not $\left(y_{i h}\right)$. In discrete choice models, logical-consistency issues [Maddala (1983)] make difficult the expression of the direct simultaneity between decisions. In particular, we cannot introduce at the same time downgrading variable in the homeownership equation and the residential status on the job downgrading equation. Consequently, we favour the direction that is relevant for our problematic. The reciprocity of the relation is taken into account indirectly by the introduction in the homeownership equation of explanatory variables explaining job downgrading. Moreover, the bivariate probit model allows correlation between error terms of the both equations (downgrading and homeownership) and so allows controlling unobserved factors that influence both processes. This interdependence is modelled by a correlation coefficient $\left(\rho_{h d}\right)$. More precisely, the formal specification of the bivariate model is the following:

$$
\begin{aligned}
& y_{i h}=\left\{\begin{array}{lll}
1 & \text { if } \quad y_{i h}^{*}=Z_{i} \gamma_{h}+u_{i h}>0 \\
0 & \text { if } \quad y_{i h}^{*}=Z_{i} \gamma_{h}+u_{i h} \leqslant 0,
\end{array}\right. \\
& y_{i d}=\left\{\begin{array}{lll}
1 & \text { if } \quad y_{i d}^{*}=y_{i h} \alpha+V_{i} \gamma_{d}+u_{i d}>0 \\
0 & \text { if } \quad y_{i d}^{*}=y_{i h} \alpha+V_{i} \gamma_{d}+u_{i d} \leqslant 0,
\end{array}\right.
\end{aligned}
$$

where the error terms $\left(u_{i h}, u_{i d}\right)$ follow a bivariate normal distribution:

$$
\left(\begin{array}{l}
u_{i h} \\
u_{i d}
\end{array}\right) \sim \mathcal{N}\left[\left(\begin{array}{l}
0 \\
0
\end{array}\right),\left(\begin{array}{cc}
1 & \rho_{h d} \\
\rho_{h d} & 1
\end{array}\right)\right]
$$


Equations (1) and (2) respectively model individual probabilities of homeownership $\left(y_{i h}=\right.$ 1 ) and job-downgrading $\left(y_{i d}=1\right)$. The $\alpha$ coefficient captures the influence of residential status on job-downgrading perceptions, with an a priori ambiguous sign. We can estimate those equations by full-information maximum likelihood (FIML) ${ }^{5}$ from observed data for individuals in employment.

However, restricting the estimation sample to employed individuals only might lead to biased estimates: a sample bias will be introduced if the socioeconomics and other personal characteristics of employed workers are significantly different from the rest of the population (unemployed and inactive individuals). Indeed, stylized facts indicate that the population in employment is for example more educated and has more labour market experience. Consequently, we propose another econometric estimation on the whole population (employed as well as non-employed individuals), and introduce an additional equation, which models the selection process into employment. Therefore, we use a recursive trivariate probit model with partial observability: we jointly estimate the equations of the residential status $\left(y_{i h}\right)$, the labour market status (employed or not) $\left(y_{i e}\right)$ and the job-downgrading status $\left(y_{i d}\right)$, which is only observed for employed individuals. The partial observability comes from the censoring of the job-downgrading variable according to the employment status. In the empirical literature, studies based on multivariate probit with partial observability are still rare and mainly implemented in bivariate specifications [Poirier (1980), Van de Ven \& Van Praag (1981), Meng \& Schmidt (1985), Mohanty (2002), Di Pietro (2004)], except Cappellari \& Jenkins (2004). The formal specification is the following:

$$
\begin{gathered}
y_{i e}=\left\{\begin{array}{lll}
1 & \text { if } & y_{i e}^{*}=X_{i} \gamma_{e}+u_{i e}>0 \\
0 & \text { if } & y_{i e}^{*}=X_{i} \gamma_{e}+u_{i e} \leqslant 0,
\end{array}\right. \\
y_{i h}=\left\{\begin{array}{lll}
1 & \text { if } & y_{i h}^{*}=Z_{i} \gamma_{h}+u_{i h}>0 \\
0 & \text { if } & y_{i h}^{*}=Z_{i} \gamma_{h}+u_{i h} \leqslant 0,
\end{array}\right. \\
y_{i d}=\left\{\begin{array}{lll}
1 & \text { if } & y_{i d}^{*}=y_{i h} \alpha+V_{i} \gamma_{d}+u_{i d}>0 \text { and } y_{i e}=1 \\
0 & \text { if } & y_{i d}^{*}=y_{i h} \alpha+V_{i} \gamma_{d}+u_{i d} \leqslant 0 \text { and } y_{i e}=1,
\end{array}\right.
\end{gathered}
$$

where the error terms $\left(u_{i e}, u_{i h}, u_{i d}\right)$ follow a trivariate normal distribution:

$$
\left(\begin{array}{l}
u_{i e} \\
u_{i h} \\
u_{i d}
\end{array}\right) \sim \mathcal{N}\left[\left(\begin{array}{l}
0 \\
0 \\
0
\end{array}\right),\left(\begin{array}{ccc}
1 & \rho_{e h} & \rho_{e d} \\
\rho_{e h} & 1 & \rho_{h d} \\
\rho_{e d} & \rho_{h d} & 1
\end{array}\right)\right] .
$$

\footnotetext{
${ }^{5}$ The associated likelihood is:

$$
\begin{aligned}
& L\left(y_{h}, y_{d} \mid V, Z\right)=\prod_{i=1}^{n}\left\{\quad \left[\Phi_{2}\left(Z_{i} \gamma_{h}, \alpha+V_{i} \gamma_{d}, \rho_{h d}\right]^{y_{i h} \cdot y_{i d}}+\left[\Phi_{2}\left(Z_{i} \gamma_{h},-\alpha-V_{i} \gamma_{d},-\rho_{h d}\right]^{y_{i h} \cdot\left(1-y_{i d}\right.}\right)\right.\right. \\
& {\left[\Phi_{2}\left(-Z_{i} \gamma_{h}, V_{i} \gamma_{d},-\rho_{h d}\right]^{\left(1-y_{i h}\right) \cdot y_{i d}}\right)+\left[\Phi_{2}\left(-Z_{i} \gamma_{h},-V_{i} \gamma_{d}, \rho_{h d}\right]^{\left(1-y_{i h}\right) \cdot\left(1-y_{i d}\right)}\right\}}
\end{aligned}
$$

with $\Phi_{2}$ the cumulative function of the standard bivariate normal distribution. 
Again, this model can be estimated by FIML because its likelihood function can be written as follows:

$$
\begin{aligned}
& L\left(y_{e}, y_{h}, y_{d} \mid X, V, Z\right)=\prod_{i=1}^{n}\left\{\quad\left[\Phi_{3}\left(Z_{i} \gamma_{e}, X_{i} \gamma_{h}, \alpha+V_{i} \gamma_{d} ; \rho_{e h}, \rho_{e d}, \rho_{h d}\right)\right]^{y_{i e} \cdot y_{i h} . y_{i d}}\right. \\
& {\left[\Phi_{3}\left(X_{i} \gamma_{e}, Z_{i} \gamma_{h},-\alpha-V_{i} \gamma_{d} ; \rho_{e h},-\rho_{e d},-\rho_{h d}\right)\right]^{y_{i e} \cdot y_{i h} .\left(1-y_{i d}\right)}} \\
& {\left[\Phi_{3}\left(X_{i} \gamma_{e},-Z_{i} \gamma_{h}, V_{i} \gamma_{d} ;-\rho_{e h}, \rho_{e d},-\rho_{h d}\right)\right]^{y_{i e} \cdot\left(1-y_{i h}\right) \cdot y_{i d}}} \\
& {\left[\Phi_{3}\left(X_{i} \gamma_{e},-Z_{i} \gamma_{h},-V_{i} \gamma_{d} ;-\rho_{e h},-\rho_{e d}, \rho_{h d}\right)\right]^{y_{i e} \cdot\left(1-y_{i h}\right) .\left(1-y_{i d}\right)}} \\
& {\left[\Phi_{2}\left(-X_{i} \gamma_{e}, Z_{i} \gamma_{h} ;-\rho_{e h}\right)\right]^{\left(1-y_{i e}\right) \cdot y_{i h}}} \\
& \left.\left[\Phi_{2}\left(-X_{i} \gamma_{e},-Z_{i} \gamma_{h} ; \rho_{e h}\right)\right]^{\left(1-y_{i e}\right) \cdot\left(1-y_{i h}\right)}\right\} \text {, }
\end{aligned}
$$

where $\phi_{3}$ and $\Phi_{3}$ are the density and the cumulative functions of the standard trivariate normal distribution, while $\phi_{2}$ and $\Phi_{2}$ corresponds to the bivariate case.

As the FIML estimation requires triple integrals calculations, we resort to simulation with the Geweke-Hajivassiliou-Keane (GHK) algorithm and our estimates are the solution of the maximization of the simulated log-likelihood [Greene (2003), Train (2003), Stern (2000), Geweke, Keane \& Runkle (1994)].

Finally, we propose to exploit the longitudinal dimension of our data to refine the control of unobserved individual heterogeneity, by using a nonparametric procedure (mass-point approach). While in the two previous models, unobserved effects are represented by random disturbances, these disturbances are now decomposed into two components. Beside a purely random component, another source of variation captures the time-invariant individual heterogeneity. This distinction is possible because repeated observations on the same individual are available. This time-invariant effect is supposed to be entirely captured by $\left(\nu_{d}, \nu_{h}, \nu_{e}\right)$ components, whose correlation account for simultaneous variations in housing and labour markets decisions that are not due to observable factors. This specification allows the isolation of individual fixed effects from purely stochastic components in each equation. We thus distinguish effects which arise from unobserved characteristics determining individual behaviour on the labour and housing markets from random variations. For example, some unobserved individual characteristics such as negotiation or organization abilities, or capacity to lead a project, might influence both the probability of homeownership (via mortgage negotiation) and the probability of downgrading. Under these conditions, the unconditional likelihood is given by:

$$
L=\int_{\nu_{d}} \int_{\nu_{h}} \int_{\nu_{e}} L\left(y_{e}, y_{h}, y_{d} \mid X, V, Z, \nu_{d}, \nu_{h}, \nu_{e}\right) d F\left(\nu_{d}, \nu_{h}, \nu_{e}\right)
$$


where

$$
\begin{aligned}
& L\left(y_{e}, y_{h}, y_{d} \mid X, V, Z, \nu_{d}, \nu_{h}, \nu_{e}\right)=\prod_{i=1}^{n}\left\{\left[\Phi_{3}\left(Z_{i} \gamma_{e}+\nu_{e}, X_{i} \gamma_{h}+\nu_{h}, \alpha+V_{i} \gamma_{d}+\nu_{d} ; \rho_{e h}, \rho_{e d}, \rho_{h d}\right)\right]^{y_{i e} . y_{i h} \cdot y_{i d}}\right. \\
& \text {. }\left[\Phi_{3}\left(Z_{i} \gamma_{e}+\nu_{e}, X_{i} \gamma_{h}+\nu_{h},-\alpha-V_{i} \gamma_{d}-\nu_{d} ; \rho_{e h},-\rho_{e d},-\rho_{h d}\right)\right]^{y_{i e} . y_{i h} .\left(1-y_{i d}\right)} \\
& \text {. }\left[\Phi_{3}\left(Z_{i} \gamma_{e}+\nu_{e},-X_{i} \gamma_{h}-\nu_{h}, V_{i} \gamma_{d}+\nu_{d} ;-\rho_{e h}, \rho_{e d},-\rho_{h d}\right)\right]^{y_{i e} \cdot\left(1-y_{i h}\right) \cdot y_{i d}} \\
& \text {. }\left[\Phi_{3}\left(Z_{i} \gamma_{e}+\nu_{e},-X_{i} \gamma_{h}-\nu_{h},-V_{i} \gamma_{d}-\nu_{d} ;-\rho_{e h},-\rho_{e d}, \rho_{h d}\right)\right]^{y_{i e} \cdot\left(1-y_{i h}\right) \cdot\left(1-y_{i d}\right)} \\
& \text {. }\left[\Phi_{2}\left(-Z_{i} \gamma_{e}-\nu_{e}, X_{i} \gamma_{h}+\nu_{h} ;-\rho_{e h}\right)\right]^{\left(1-y_{i e}\right) \cdot y_{i h}} \\
& \text {. } \left.\left[\Phi_{2}\left(-Z_{i} \gamma_{e}-\nu_{e},-X_{i} \gamma_{h}-\nu_{h} ; \rho_{e h}\right)\right]^{\left(1-y_{i e}\right) \cdot\left(1-y_{i h}\right)}\right\} \text {, }
\end{aligned}
$$

and where $\mathrm{F}$ (.) is the cumulative distribution function of unobserved heterogeneity terms.

In practice, it is necessary to define the joint function $F($.$) of the unobserved heterogeneity$ variables $\left(\nu_{d}, \nu_{h}, \nu_{e}\right)$. Following Hoynes (1996) and in the spirit of Heckman \& Singer (1984), we assume that these terms follow a discrete distribution with a finite number realizations. More precisely, we adopt the non-parametric mass-point approach for $F($.$) by assuming that$ individuals are distributed with probability $p$ in two types. Each of them are defined by a vector of mass points $\nu_{1}=\left(\nu_{d}^{1}, \nu_{h}^{1}, \nu_{e}^{1}\right)$ with probability $p=p_{1}=\operatorname{Pr}\left(\nu_{d}=\nu_{d}^{1}, \nu_{h}=\nu_{h}^{1}, \nu_{e}=\nu_{e}^{1}\right)$ and $\nu_{2}=\left(\nu_{d}^{2}, \nu_{h}^{2}, \nu_{e}^{2}\right)$ with probability $p_{2}=(1-p)$. The simplest specification for the joint distribution is taken, allowing for two points for each unobservable $(q=1,2)$. The estimated unconditional likelihood function is obtained by summing over the unobserved heterogeneity components, i.e. by replacing the integration in equation (9) by a finite summation sign:

$$
L=\sum_{q=1}^{2} p_{q} \cdot L\left(y_{e}, y_{h}, y_{d} \mid X, V, Z, \nu_{d}^{q}, \nu_{h}^{q}, \nu_{e}^{q}\right) .
$$

As the parameters $p_{1}$ and $p_{2}$ must belong to the interval $[0,1]$ and their sum must be equal to 1 , we write $p_{q}$ as logit functions : $p_{1}=1 /\left(1+\exp \left(\pi_{1}\right)\right)$ and $p_{2}=\exp \left(\pi_{1}\right) /\left(1+\exp \left(\pi_{1}\right)\right)$. Therefore, in practice, the parameter $\pi_{1}$ is estimated and the probability $p_{1}$ and $p_{2}$ are next calculated.

In section 4, the three previous models are applied to French data set of the 1995-2001 European Community Household Panel to evaluate the impact of the residential status on the job-match quality perceptions. Comparing estimation results allow assessing the influence of selection into employment and of unobserved heterogeneity.

\section{Data}

\subsection{The French data set of the ECHP and sample description}

The European Community Household Panel stems from the project of constitution of a European longitudinal individual database under the initiative of Eurostat. The French part was 
collected by INSEE, between 1995 and 2001, and contains 18916 individuals representing 7344 households at the beginning of the survey. The European panel enables the tracking of mobile individuals, their trajectories on the labour market and their living conditions, in particular with regards to housing. However, we restrict the database to individuals between seventeen and sixty years old, living in a conventional household. We exclude households constituted by families implying indirect ascendants, or more than one direct ascendant, as well as, households which are not families. Also, we do not examine children still living in the parental home, whose trajectories, both on the labour and housing markets, follow specific paths [see Chambaz (2001) and Laferrère (2005)]. For employed individuals, we retained only clerks, workers, intermediate and intellectual occupations and discard farmers and craftsmen. Moreover, we only consider individuals who are either homeowners or renters in the private sector, and skip social sector renters in order to keep a homogeneous category for renters. Links between social housing sector and labour market outcomes require a specific research. Finally, our sample accounts for approximately 7700 individuals and 5000 households for which information relative to labour and housing markets is available. It corresponds to 18654 observations, displaying a homeownership rate equal to $75 \%$. Table 1 presents the descriptive statistics, distinguishing homeowners and renters.

In France, households willing to purchase their home generally face two types of requirements from banks and credit institutions. One regards the amount of initial down payment as the mortgage cannot exceed some fraction of the housing value. Beside, household earnings are evaluated with respect to the monthly repayments that are entailed by the mortgage. Given these institutional constraints on credit access, it is not surprising to observe from Table 1 that homeowners are more often in employment than renters, and that dual-earner households more frequently own their homes. We also note that individuals employed in the public sector are more often homeowners compared to individuals working in the private sector, given that civil servants are usually more stable in employment and have more certain future income streams. According to life-cycle process, as well as down payment constraints, homeowners are on average older and have more labour market experience than private renters.

Table 2 describes the distribution by gender, age, level of diploma and labour market experience of individuals according to their professional (employed or not) and residential (owner or renter) statuses. Homeowners are on average older than renters, but those who are employed tend to be relatively younger. This observation turns out valid for renters also. These age differences mirror the distribution of individuals in terms of their labour market experience: two thirds of the owners have more than twenty years of working experience, against hardly a third for renters. Regarding individuals who have been on the labour market less than 10 years, only $7 \%$ are homeowners. Globally, owners are more represented at the lowest educational levels (no diploma, secondary education certificate, technical education) and less at higher education levels. We also note that employed individuals, whether they are owners or renters, have more human capital endowments than the inactive or unemployed individuals. Since there are clear cut differences between employed and not employed individuals, there is no reason to believe that the remaining sample after exclusion of non-employed individuals would 
Table 1: SAMPle INDIVIDUAl CHARACTERISTICS FOR HOMEOWNERS AND PRIVATE RENTERS

\begin{tabular}{|c|c|c|c|}
\hline & Homeowners & Renters & Total \\
\hline \multicolumn{4}{|l|}{ Labor market status } \\
\hline Inactivity & 22.33 & 12.51 & 19.97 \\
\hline Unemployment & 6.12 & 9.62 & 6.97 \\
\hline Employment & 71.55 & 77.86 & 73.07 \\
\hline Female & 0.53 & 0.51 & 0.53 \\
\hline Foreign nationality & 0.03 & 0.05 & 0.03 \\
\hline \multicolumn{4}{|l|}{ Household type } \\
\hline Couple, no child. & 0.23 & 0.27 & 0.24 \\
\hline Couple w. children & 0.69 & 0.52 & 0.65 \\
\hline Single-parent family & 0.03 & 0.06 & 0.04 \\
\hline Single person & 0.05 & 0.15 & 0.07 \\
\hline \multicolumn{4}{|l|}{ Spouse's status } \\
\hline Employed spouse & 0.69 & 0.59 & 0.67 \\
\hline Unemployed spouse & 0.05 & 0.08 & 0.05 \\
\hline Inactive spouse & 0.15 & 0.11 & 0.14 \\
\hline NA & 0.04 & 0.01 & 0.03 \\
\hline \multicolumn{4}{|l|}{ Age } \\
\hline 17-29 years & 0.04 & 0.29 & 0.10 \\
\hline 30-39 years & 0.27 & 0.37 & 0.29 \\
\hline 40-49 years & 0.37 & 0.21 & 0.33 \\
\hline $50-60$ years & 0.32 & 0.13 & 0.27 \\
\hline \multicolumn{4}{|l|}{ Highest degree } \\
\hline No diploma or second. & 0.36 & 0.26 & 0.34 \\
\hline Short technical educ. & 0.34 & 0.33 & 0.34 \\
\hline Long tech. educ., highschool cert. & 0.14 & 0.18 & 0.15 \\
\hline Under. High. educ. & 0.10 & 0.14 & 0.11 \\
\hline Grad. High. educ. & 0.05 & 0.09 & 0.06 \\
\hline \multicolumn{4}{|l|}{ Labor market experience } \\
\hline$<=5$ years & 0.01 & 0.11 & 0.03 \\
\hline $6-10$ years & 0.05 & 0.21 & 0.09 \\
\hline $11-20$ years & 0.24 & 0.33 & 0.26 \\
\hline$>20$ years & 0.70 & 0.34 & 0.61 \\
\hline \multicolumn{4}{|l|}{ Occupation } \\
\hline Clerk & 0.37 & 0.36 & 0.37 \\
\hline Worker & 0.28 & 0.28 & 0.28 \\
\hline Intellectual prof. & 0.10 & 0.11 & 0.10 \\
\hline Intermediate prof. & 0.25 & 0.25 & 0.25 \\
\hline \multicolumn{4}{|l|}{ Sector } \\
\hline Private sector & 0.47 & 0.56 & 0.49 \\
\hline Public sector & 0.23 & 0.21 & 0.23 \\
\hline NA & 0.30 & 0.23 & 0.28 \\
\hline Inheritance or donation & 0.05 & 0.04 & 0.05 \\
\hline
\end{tabular}

Source: 1995-2001 ECHP, authors' calculations

be random. Discarding non-employed individuals is likely to generate a sample selection bias, 
an expectation that will be checked when comparing results from the bivariate and trivariate models.

Table 2: Individual Features, By professionnal and Residential statuses

\begin{tabular}{|c|c|c|c|c|}
\hline & \multicolumn{2}{|c|}{ Homeowners } & \multicolumn{2}{|c|}{ Renters } \\
\hline & Empl. & Non-Empl. & Empl. & Non-Empl. \\
\hline Female & 0.45 & 0.74 & 0.45 & 0.71 \\
\hline \multicolumn{5}{|l|}{ Age } \\
\hline 17-29 years & 0.05 & 0.03 & 0.30 & 0.25 \\
\hline 30-39 years & 0.31 & 0.17 & 0.38 & 0.33 \\
\hline 40-49 years & 0.42 & 0.23 & 0.21 & 0.21 \\
\hline $50-60$ years & 0.22 & 0.56 & 0.11 & 0.20 \\
\hline \multicolumn{5}{|l|}{ Highest degree } \\
\hline No diploma or second. & 0.31 & 0.49 & 0.24 & 0.35 \\
\hline Short technical educ. & 0.36 & 0.29 & 0.34 & 0.31 \\
\hline Long tech. educ., highschool cert. & 0.15 & 0.12 & 0.18 & 0.18 \\
\hline Under. High. educ. & 0.12 & 0.07 & 0.15 & 0.10 \\
\hline Grad. High. educ. & 0.06 & 0.02 & 0.10 & 0.06 \\
\hline \multicolumn{5}{|l|}{ Labor market exp. } \\
\hline$<=5$ years & 0.01 & 0.01 & 0.12 & 0.06 \\
\hline $6-10$ years & 0.06 & 0.03 & 0.23 & 0.15 \\
\hline $11-20$ years & 0.27 & 0.15 & 0.33 & 0.35 \\
\hline$>20$ years & 0.66 & 0.81 & 0.32 & 0.43 \\
\hline
\end{tabular}

\subsection{Homeownership and job downgrading}

The ECHP contains questions that provide enough information to assess the job-match quality from a subjective perspective. More precisely, workers are allocated to the different types of job match according to their responses to the following question: "Do you feel you have skills or qualifications to do a more demanding job than the one you have now?". People reporting an affirmative answer are considered overqualified $^{6}$. The definition of subjective job-downgrading we retain here is identical to those of recent investigations on overeducation with the ECHP data [Alba-Ramirez \& Blázquez (2003), Budria \& Moro-Egido (2009)]. This subjective measure might raise some problems related to employees' overestimation of the required skills for their job, so that they can give more value to their professional activity. Moreover, worker's self-assessment might reproduce current hiring standards: if schooling levels increase on the labour market and employers adapt their hiring standards, the stated necessary schooling level increases while the job tasks do not change [Sicherman (1991)]. The subjective measure of the job-match quality might thus be upward biased as mentioned by Hartog \&

\footnotetext{
${ }^{6}$ We do not investigate potential discrepancies between qualifications and skills mismatch : see Quintini (2011) for a review on the literature on this topic.
} 
Oosterbeek (1988). Nonetheless, insofar as downgrading feeling influences motivation and thus productivity (see e.g.Green \& Zhu (2010)), the objective content of the downgrading assessment is not of prime importance for our matter of concern. Beside, evaluating the impact of the homeownership on the job-downgrading requires only a relative measure of the job-match quality that is comparable for the two groups.

Table 3: Job DOWNGRAding AND RESIDENTIAL STATUS

\begin{tabular}{lcccccc}
\hline Subjective & \multicolumn{2}{c}{ Homeowners } & \multicolumn{2}{c}{ Renters } & \multicolumn{2}{c}{ Total } \\
downgrading & Number & Pct & Number & Pct & Number & Pct \\
\hline No & 5924 & $48.2 \%$ & 1827 & $43.2 \%$ & 7751 & $46.9 \%$ \\
Yes & 6366 & $51.8 \%$ & 2404 & $56.8 \%$ & 8770 & $53.1 \%$ \\
Total & 12290 & $100 \%$ & 4231 & $100 \%$ & 16521 & $100 \%$ \\
\hline Source: 1995-2001 ECHP, authors' calculations & & &
\end{tabular}

We see in Table 3 that $53 \%$ of all wage earners have the perception to be job downgraded. This figure is close to what Budria \& Moro-Egido (2009) find with the 2001 wave of the ECHP and the same definition of job downgrading: the incidence of overqualified workers in Europe is $59.5 \%$ ranging from $41.6 \%$ in Portugal to $68.3 \%$ in the United Kingdom, while the proportion of overqualified workers is equal to $55 \%$ in France. The small difference with our study probably comes from our sample restrictions and from the fact we use seven waves of the $\mathrm{ECHP}^{7}$. Unfortunately, the proportion of overqualified workers can hardly be compared with previous studies and other data: indeed, the empirical evidence on job downgrading remains limited for France, most of the studies having dealt with young graduates on their first job [Forgeot \& Gautié (1997), Giret (2005), Nauze-Fichet \& Tomasini (2002, 2006), Giret, Nauze-Fichet \& Tomasini (2006), di Paola \& Moullet (2009)] or higher education graduates [Guironnet (2006), Guironnet \& Peypoch (2007)]. According to Hartog (2000), the incidence of overqualification varies from $10 \%$ to $35 \%$ in some European countries (Netherlands, Spain, Portugal and the United Kingdom), depending on the measure (normative or statistical). It is also not surprising to obtain a higher job downgrading rate with the subjective approach.

Table 3 shows that renters feel more frequently downgraded than owners. However, this descriptive result is not sufficient to infer that homeowners have advantageous positions on the labour market. Indeed, homeowners and renters are not homogeneous categories, and we thus estimate econometric models in order to control the influence of other covariates (education level, age, labour market experience) in both processes of interest.

\footnotetext{
${ }^{7}$ For the 1995 survey, Alba-Ramirez \& Blázquez (2003) find an overqualification rate equal to 53.8\% in Spain against 59.4\% for Budria \& Moro-Egido (2009) for the 2001 survey.
} 


\section{Results}

Three specifications are compared to illustrate the econometric issues: a bivariate model on the sample of employed individuals, a trivariate model which takes into account the selection in employment, and a trivariate model which in addition refines the control of unobserved heterogeneity. According to the empirical literature [Battu, Belfield \& Sloane (2000), NauzeFichet \& Tomasini $(2002,2006)$, Giret et al. (2006)] we retain in all specifications the following explanatory variables $V$ for job-downgrading: sociodemographic characteristics (gender, age, experience, nationality, family structure, education levels, urban area size) ; job and firm characteristics (occupation type, public/private job, sector of activity) ; residential status variable. Given the partial observability of the job downgrading variable, job and firm characteristics are only introduced in the downgrading equation.

For the residential status equation, we retain standard demographic features (gender, age, family structure, etc). An empirical regularity is to observe a higher homeownership probability for women. According to the life cycle, we expect that older individual are more likely to be homeowners. The family structure of the individual is also considered: couples with children being more susceptible to be owners, whereas the opposite is expected for single persons. Moreover, because of the recursivity of our models, we have to impose exclusion restrictions ${ }^{8}$ in order to identify the model's parameters: at least one of the regressors in the residential status equation, as well as, in the employment equation for the trivariate models, has to be excluded from the downgrading equation. We use two instrumental variables, which are determinants of the residential status choice, while without effects on the job downgrading. The first variable indicates whether the individual benefited from or donated an inheritance during the preceding survey wave. The underlying hypothesis is that this past-wave event does not modify individuals current overqualification feeling, whereas it increases the probability of homeownership. This seems reasonable to the extent that one-shot donations usually correspond to capital amounts that are not big enough compared to labour income streams to induce a job-change. However, this extra-capital might help to constitute the required initial down-payment that is required for a home purchase. Secondly, we calculated quantiles of the average local taxes (land tax and local residence tax), by urban area size and "départements". We expect those variables to represent local amenities which increase the probability of homeownership without modifying labour market behaviours. Local taxes might also capture negative housing costs effects. Consequently, their global impact needs to be empirically determined.

As regards the exclusion restriction to identify the probability of employment, we use an indicator of the professional status of the individual's mother. More precisely, the variable indicates whether the individual's mother was inactive or not, by the time the individual entered the labour market. We hope to reproduce an intergenerational transmission effect of attitude toward professional activity, while this variable should not influence residential status choice, nor the individual's job match. Otherwise, usual determinants of employment access

\footnotetext{
${ }^{8}$ See Maddala (1983) for a review of identification conditions in simultaneous equations recursive models.
} 
are used, such as gender, age, education level, labour market status of the spouse. We expect that access to employment is favoured by schooling level. Effects of the spouse's professional status are undetermined as they depend on the decision making process among partners with respect to their labour supply, domestic work sharing and income sharing [see e.g. Clark, Couprie \& Sofer (2004)].

Estimation results of the three specifications are reported in Appendix. A synthesis of residential status effects on the job downgrading is given in Table 4 .

\subsection{Determinants of tenure choice}

Results obtained from the homeownership equation are globally similar (in terms of significant variables and coefficients magnitude) across the three specifications and are in line with usual findings. For example, ceteris paribus, the probability of being an owner increases with age, which is consistent with the traditional effects of the life cycle theory. The size of the residential urban area decreases the probability of homeownership, as does the localization in the Parisian area. Indeed, land-use constraints and housing market tensions in densely populated areas typically lower accession to homeownership. All other factors being equal, women have a higher probability to be homeowners [an empirical regularity which is obtained among others by Munch et al. (2006) and van Vuuren (2009)]. With respect to couples without children, those living in couples with children have a significantly higher probability to have chosen for homeownership; we observe the opposite for single-parent families and single individuals. The professional status of the spouse plays an important role: individuals whose spouse is employed have a higher probability of being owners. The negative effect of having an unemployed spouse is relatively greater than figures obtained when the spouse is inactive.

Whereas schooling level exerts some influence on residential status, there is no formal hierarchy between degrees. Individuals with long technical education or high school certificate are more often homeowners than people with graduate higher education. Meanwhile, these two groups have a higher probability of homeownership with respect to individuals holding a short technical degree, or an undergraduate degree. Indeed, labour market prospects (in terms of career start or progress) are usually better for these two aforementioned groups. We note as well that labour market experience favours homeownership status.

Finally, instruments used in the residential status equation are significant: having received an inheritance or made a donation is associated with a higher probability of homeownership. Local taxes exert a positive and significant effect on the probability of homeownership : the influence of local amenities seems to overcome that of housing costs. Summing up, our results regarding the determinants of homeownership in France are globally in line with usual findings. 


\subsection{Selection into employment}

Most of the estimated coefficients which are predictors of the employment probability are similar across the two trivariate models (Tables 6 and 7). First of all, the instrument, namely the individual's mother inactivity status, exerts a significant and negative effect as expected. Women have a lower probability to be employed, other things being equal, and family structure, in particular the presence of children, plays an important role on labour market participation. Individuals living in couples tend to be more often non-employed when their partner is not working. Foreigners have a lower employment probability, highlighting employment access difficulties of populations who are likely to be discriminated on the labour market or to lack employment opportunities because of skill shortage, in particular with respect to language.

Age does not appear to be a strong determinant of employment probability, although this is only true before the age fifty: afterward, professional activity is significantly reduced. Schooling level raise employment probabilities, with effects conforming to the hierarchy of degrees. Compared to rural areas, the localization in the Parisian region favours employment access, as does residency in large urban areas. Conversely, individuals are more likely to be out of employment when they live in medium size urban areas (10 000 to 20000 inhabitants).

Lastly, time indicators exert positive and increasing effects compared to 1995: indeed, survey years correspond to the decrease in the unemployment rate over the period 1995 to 2001 ; this also reflects the fact that employed individuals at the beginning of the survey tend to stay under observation.

These results suggest that selection into employment is properly taken into account through the trivariate model.

\subsection{Determinants of subjective downgrading}

Before addressing the residential status influence on subjective downgrading, we detail the effects of the other explanatory variables. Most of the sociodemographic characteristics play significantly on the individual perceptions of downgrading.

Women and foreigners have significantly lower subjective downgrading probability, with respect to men or to French individuals. Although the existence of pure or statistical discrimination against these two groups is well documented [for France, see for example Meurs \& Ponthieux (2000), Havet \& Lacroix (2003), Meurs \& Ponthieux (2006), Tanay \& Audirac (2001), Garner-Moyer (2003)], these results indicate that the appropriate reference standard of each group is probably not these individuals to whom we compare them [Clark (1997)]. For instance, if women anticipate that they will have more difficulties than their male counterparts to reach "good" jobs, they probably integrate the existence of a differential situation as more or less inescapable, and so have a more positive perception for the jobs which they occupy. 
Age also influences individual perception of the adequacy of one's skills to the job: with regard to the youngest, individuals in their thirties or forties feel more downgraded. However, beyond fifty years, age exercises no additional impact. We also note that labour market experience does not influence subjective downgrading probability. According to the job-matching theory, job-match quality improves along the career path, which is not the perception of the workers.

The probability of subjective downgrading increases with the urban area size, although there is no clear hierarchy. One might conjecture that competition between workers and employers power are stronger in densely populated local labour markets. Conversely, employers might find it less desirable to under-value their employees skills in rural areas where individuals are relatively less willing to move.

Effects related to standard internalization according to the reference group, also show up through the impact of the individual occupational category: being in intellectual or intermediate professions decreases subjective downgrading, as well as being in a blue collar job (with regards to the white collars). Working in the public sector decreases subjective downgrading. This result is in line with di Paola \& Moullet (2009) who find that civil servant status reduces the overqualification feeling for entrants on the labour market. We find sector-based impacts that are negative with regards to the business sector (except for the shipping industry).

Lastly, the more educated the individuals are, the more they fell downgraded, i.e. the more they think that they could work in a job demanding higher qualifications. The educational level is a crucial determinant of the job-match quality perceptions (and thus job satisfaction) because workers probably tend to compare themselves with workers with identical diploma, which is most of times a public information.

Our results show that individuals seem to assess the quality of their job-match by comparing themselves mainly to similar workers in terms of gender, nationality, age or diploma.

\subsection{Homeownership impact on job downgrading}

We now turn to estimated homeownership coefficients, reported in Table 4, and in doing so, we also examine whether they are sensitive to the econometric specification.

Firstly, we can emphasize that the correlation coefficients $\rho_{h d}$ between the homeownership and job downgrading equations are statistically significant in the three models. Some unobserved characteristics play simultaneously on the likelihood of homeownership and the risk of job downgrading. More precisely, there are unobserved factors which increase simultaneously the homeownership probability and the subjective downgrading probability. As mentioned earlier, if owners are characterized by specific skills in terms of negotiation or organization, they are more likely to be sensitive to a relative inadequacy between their skills and job. In other words, homeowners would have higher requirements and feel more easily downgraded in a job which is not a good match. Homeownership being a socially valued status, it is possible 
Table 4: InfLUENCE OF RESIDENTIAL STATUS ON DOWNGRADING: SYNTHESIS

\begin{tabular}{|c|c|c|c|c|c|c|}
\hline \multirow{3}{*}{$\begin{array}{l}\text { Coeff. } \\
\text { Homeownership }\end{array}$} & \multicolumn{6}{|c|}{ Probit specifications } \\
\hline & \multicolumn{2}{|c|}{ Bivariate } & \multicolumn{2}{|c|}{ Trivariate } & \multicolumn{2}{|c|}{ Trivariate with heterog. } \\
\hline & $-0.509^{* * *}$ & $(0.18)$ & $-0.349^{* * *}$ & $(0.13)$ & -0.180 & $(0.18)$ \\
\hline \multicolumn{7}{|l|}{ Correlations } \\
\hline$\rho_{h d}$ & $0.271^{* *}$ & $(0.11)$ & $0.180^{*}$ & $(0.07)$ & $0.270 * * *$ & $(0.10)$ \\
\hline$\rho_{e d}$ & & & $0.503^{* * *}$ & $(0.12)$ & 0.323 & $(0.21)$ \\
\hline$\rho_{h e}$ & & & $0.113^{* * *}$ & $(0.02)$ & $0.305^{* * *}$ & $(0.05)$ \\
\hline \multicolumn{7}{|l|}{ Heterogeneity } \\
\hline$\nu_{e}^{1}$ & & & & & $1.353^{* * *}$ & $(0.11)$ \\
\hline$\nu_{h}^{1}$ & & & & & $-0.644^{* * *}$ & $(0.08)$ \\
\hline$\nu_{d}^{1}$ & & & & & -0.095 & $(0.15)$ \\
\hline$\nu_{e}^{2}$ & & & & & $3.303^{* * *}$ & $(1.34)$ \\
\hline$\nu_{h}^{2}$ & & & & & $-0.428 * * *$ & $(0.13)$ \\
\hline & & & & & $1.530^{* * *}$ & $(0.39)$ \\
\hline \multicolumn{7}{|c|}{ Probabilities of each type } \\
\hline$p_{1}$ & & & & & $0.736^{* * *}$ & $(0.04)$ \\
\hline$p_{2}=\left(1-p_{1}\right)$ & & & & & $0.264^{* * *}$ & $(0.04)$ \\
\hline
\end{tabular}

Notes : Significance: $\quad *: 10 \% \quad * *: 5 \% \quad * * *: 1 \%$, standard errors in parenthesis.

$\rho_{h i}$ is the correlation coefficient between the residential status equation and the employment equation $(i=e)$ or the downgrading equation $(i=d), \rho_{e d}$ is the correlation coefficient between the employment equation and the downgrading equation.

that individuals having chosen this housing tenure are particularly sensitive to be employed in a job where they can obtain a recognition of their skills. This result highlight the importance of jointly estimating residential status choice and job-match quality perceptions indicators.

According to the bivariate model, owners more often declare not feeling downgraded, all other things being equal. When the estimation takes into account the selection into employment, the homeownership coefficient decreases slightly and remains statistically significant. Besides, unobserved factors in each equation are positively correlated, but the correlation between downgrading and homeownership equations falls. Part of the effect is now translated in the positive correlation between unobserved factors that increase homeownership probability and those affecting the employment status on one hand, and factors favouring the employment probability and increasing subjective downgrading on the other hand. It is nevertheless delicate to interpret this last effect as it is. In the bivariate specification, which was estimated on a selected sample of employed individuals, a part of the homeownership coefficient actually reflected the higher propensity of homeowners to be in employment.

The trivariate estimation modelling unobserved individual heterogeneity with non-parametric procedure allows to give more precise explanations. This model separates what originates from purely stochastic disturbances from fixed effect related to unobserved attributes. Its results show that the homeownership variable in the two previous econometric specifications actually 
captured individual heterogeneity. Indeed, the residential status as such does not affect any more the subjective downgrading probability. Besides, correlation coefficients between homeownership equation and, respectively, that of the employment and the downgrading equations, remain positive and significant, whereas the correlation between employment and downgrading equations is no more significant.

Estimated heterogeneity terms for every equation and the probability associated with each type of individuals indicate that the employed population is distributed in two groups. In the first group, individuals present particular unobserved characteristics that result in lower employment and homeownership propensities, without any influence on the downgrading feeling. In the second group, unobserved attributes simultaneously contribute to an increase of employment, homeownership and subjective downgrading probabilities. The mechanisms which were described above are thus clarified and put in perspective according to the existence of these two types. It seems that a part of the owners population is intrinsically characterized by a higher probability of feeling downgraded, once taken into account observable characteristics. Higher mobility costs of this group of owners might restrict job opportunities at career start and then limit job transitions which could improve their job match. As such this result raises the hypothesis of a lower productivity in employment of owners, as far as productivity is influenced by job satisfaction, of which the downgrading feeling is one dimension.

\section{Conclusion}

In order to gain new insights about the benefits and the drawbacks of homeownership, this paper studies the effect of homeownership on job-match quality perceptions. We also complement the literature on the consequences of residential status, not only on labour markets outcomes, but also on individual satisfaction and perceptions. We use a subjective job downgrading measure, available from the French data set of the 1995-2001 European Household Panel Survey. We try to provide a robust econometric method by dealing with the endogeneity issue and unobserved individual heterogeneity. We estimate three specifications: i) a bivariate model on the sample of employed individuals, which simultaneously models the residential status choice and its impact on the probability to be downgraded; ii) a trivariate model with partial observability which takes into account the selection into employment and is estimated on the whole population (employed and not-employed individuals); iii) a trivariate model which in addition refines the control of unobserved heterogeneity, by using the longitudinal dimension of the dataset.

Comparing the three models shows that taking into account the selection into employment and controlling unobservable individual heterogeneity are of prime necessity to obtain robust conclusions. While in the two former models homeownership has a negative and significant influence on job downgrading perceptions, the most relevant specification concludes to no

significant effect. The estimated heterogeneity terms in this latter model indicate that part of the homeowners population is characterized by a higher probability of downgrading perception 
than private renters. Consequently, homeownership could be associated to some harmful effects on the job-match quality. Our results contradict some recent papers which have established better labour outcomes for homeowners, through lower unemployment risk [van Leuvensteijn \& Koning (2004), de Graaff \& van Leuvensteijn (2007), van Vuuren (2009) and Brunet et al. (2011)] or higher wage [Munch et al. (2008) and Brunet, Havet \& Lesueur (2010)] than the private renters. This homeownership "premium" on the labour market could be lowered when taking into account job-match quality as measured by employees self-assessments. Whereas realized job-matches by homeowners might not be of a lesser quality with respect to objective or statistical measures (a point that would deserve further investigation), the downgrading feeling of (part of) homeowners might be a source of a lower motivation, and might thus lead to a lower productivity and career development. Extensions of our analysis to other measures of job satisfaction would nicely complement the present study. 


\section{Appendix}

Table 5: BIVARIATE MODEL OF THE DOWNGRADING AND HOMEOWNERSHIP PROBABILITIES

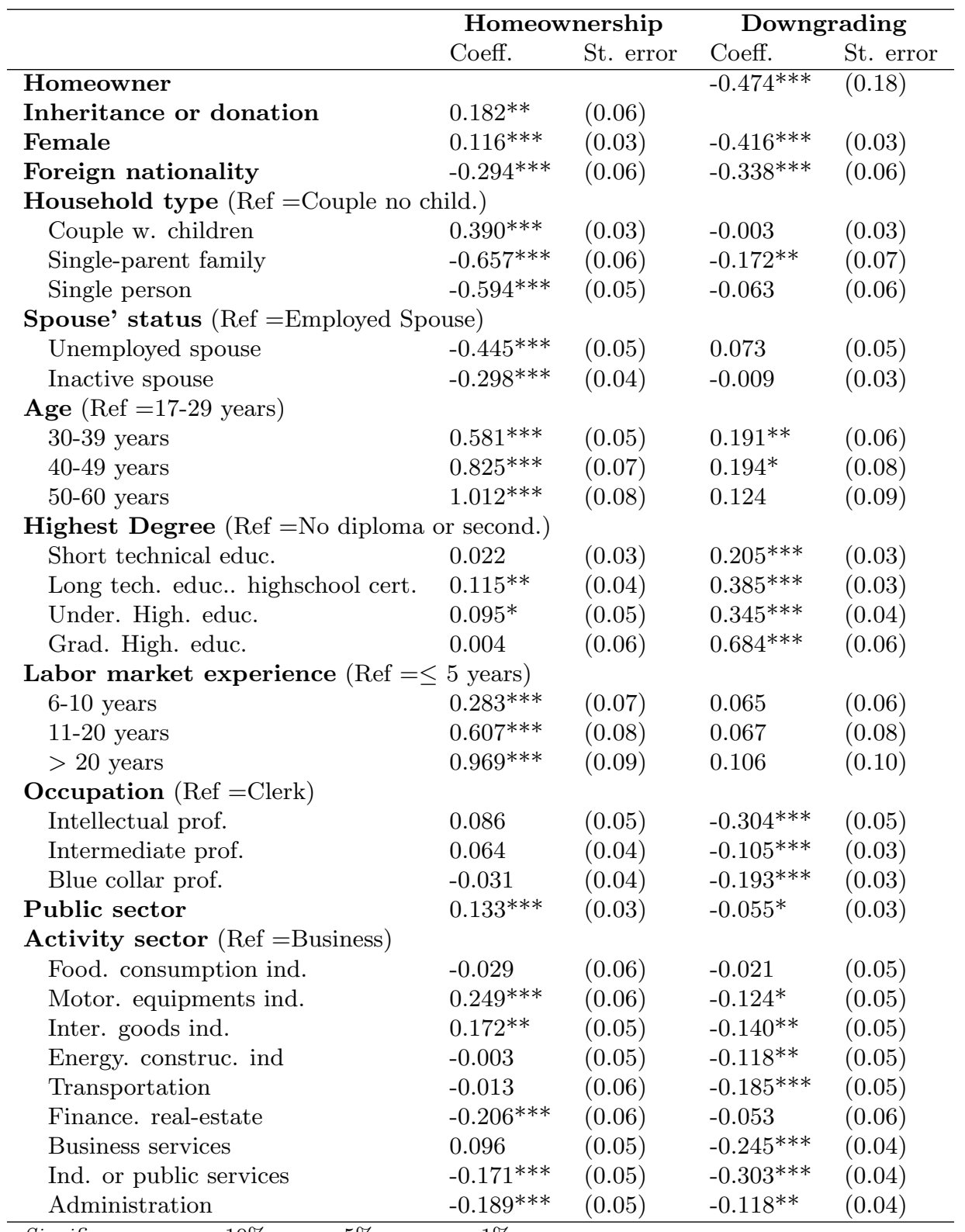

Significance : $\quad *: 10 \% \quad * *: 5 \% \quad * * *: 1 \%$. 
Table 5: Bivariate MODEL OF THE DOWNGRAding AND HOMEOWNERship PROBABILITIES (Continued)

\begin{tabular}{|c|c|c|c|c|}
\hline & \multicolumn{2}{|c|}{ Homeownership } & \multicolumn{2}{|c|}{ Downgrading } \\
\hline & Coeff. & St. error & Coeff. & St. error \\
\hline \multicolumn{5}{|c|}{ Urban area size $($ Ref $=$ rural area $)$} \\
\hline$<5000$ inhabitants & $-0.290 * * *$ & $(0.06)$ & 0.029 & $(0.05)$ \\
\hline$[5000-10000[$ inhabitants & $-0.503^{* * *}$ & $(0.05)$ & $0.140^{* *}$ & $(0.05)$ \\
\hline$[10000-20000[$ inhabitants & $-0.560 * * *$ & $(0.05)$ & -0.043 & $(0.05)$ \\
\hline$[20000-50000[$ inhabitants & $-0.581^{* * *}$ & $(0.05)$ & $-0.181^{* * *}$ & $(0.05)$ \\
\hline$[50000-100000[$ inhabitants & $-0.459^{* * *}$ & $(0.06)$ & $0.123^{*}$ & $(0.05)$ \\
\hline$[100000-200000[$ inhabitants & $-0.495^{* * *}$ & $(0.05)$ & $0.116^{* *}$ & $(0.04)$ \\
\hline$[100000-2000000[$ inhabitants & $-0.631^{* * *}$ & $(0.04)$ & 0.040 & $(0.04)$ \\
\hline Parisian area & $-0.628^{* * *}$ & $(0.05)$ & $0.146^{* * *}$ & $(0.04)$ \\
\hline \multicolumn{5}{|c|}{ Amount of Local taxes (Ref $=<370$ euros) } \\
\hline$[370-470[$ & $0.195 * * *$ & $(0.04)$ & & \\
\hline$[470-580[$ & $0.384^{* * *}$ & $(0.04)$ & & \\
\hline$[580-750[$ & $0.342^{* * *}$ & $(0.04)$ & & \\
\hline$[750$ and +[ & $0.350^{* * *}$ & $(0.04)$ & & \\
\hline \multicolumn{5}{|l|}{ Year $($ Ref $=1995)$} \\
\hline 1996 & 0.000 & $(0.04)$ & 0.000 & $(0.03)$ \\
\hline 1997 & 0.013 & $(0.04)$ & -0.014 & $(0.03)$ \\
\hline 1998 & 0.010 & $(0.04)$ & -0.041 & $(0.03)$ \\
\hline 1999 & 0.051 & $(0.04)$ & -0.037 & $(0.04)$ \\
\hline 2000 & 0.012 & $(0.04)$ & -0.060 & $(0.04)$ \\
\hline 2001 & -0.001 & $(0.04)$ & $-0.075^{*}$ & $(0.04)$ \\
\hline Constant & $-0.781^{* * *}$ & $(0.08)$ & $0.444^{* * *}$ & $(0.08)$ \\
\hline Correlation & $\rho_{h d}=0.251^{* *}$ & $(0.11)$ & & \\
\hline$\chi^{2}$ & 4511.529 & & & \\
\hline Obs. nb. & 16489 & & & \\
\hline Log-likeli. & -18241.079 & & & \\
\hline
\end{tabular}


Table 6: Trivariate model: Subjective downgrading, Homeownership and Partial OBSERVABILITY

\begin{tabular}{|c|c|c|c|c|c|c|}
\hline \multirow{2}{*}{ Homeowner } & \multicolumn{2}{|c|}{$\begin{array}{l}\text { Employment } \\
\text { Coef. and s.e. }\end{array}$} & \multicolumn{2}{|c|}{$\begin{array}{l}\text { Homeownership } \\
\text { Coef. and s.e. }\end{array}$} & \multicolumn{2}{|c|}{$\begin{array}{l}\text { Downgrading } \\
\text { Coef. and s.e. }\end{array}$} \\
\hline & & & & & $-0.349^{* *}$ & $(0.13)$ \\
\hline Inheritance or donation & & & $0.200 * * *$ & $(0.05)$ & & \\
\hline Mother was inactive & $-0.071^{* * *}$ & $(0.02)$ & & & & \\
\hline Female & $-0.930 * * *$ & $(0.02)$ & $0.055^{*}$ & $(0.02)$ & $-0.569 * * *$ & $(0.04)$ \\
\hline Foreign nationality & $-0.155^{*}$ & $(0.06)$ & $-0.265^{* * *}$ & $(0.06)$ & $-0.353^{* * *}$ & $(0.06)$ \\
\hline \multicolumn{7}{|c|}{ Household type (Ref =Couple no child. $)$} \\
\hline Couple w. children & $-0.059^{*}$ & $(0.03)$ & $0.284^{* * *}$ & $(0.03)$ & $-0.093^{* *}$ & $(0.03)$ \\
\hline Single-parent family & $0.135^{*}$ & $(0.06)$ & $-0.726^{* * *}$ & $(0.06)$ & $-0.205^{* *}$ & $(0.07)$ \\
\hline Single person & -0.067 & $(0.05)$ & $-0.741^{* * *}$ & $(0.05)$ & $-0.182^{* * *}$ & $(0.06)$ \\
\hline \multicolumn{7}{|c|}{ Spouse' status (Ref =Employed Spouse) } \\
\hline Unemployed spouse & $-0.248^{* * *}$ & $(0.05)$ & $-0.436^{* * *}$ & $(0.05)$ & 0.041 & $(0.05)$ \\
\hline Inactive spouse & $-0.214^{* * *}$ & $(0.03)$ & $-0.208^{* * *}$ & $(0.04)$ & -0.008 & $(0.04)$ \\
\hline \multicolumn{7}{|l|}{ Age $($ Ref $=17-29$ years $)$} \\
\hline 30-39 years & 0.062 & $(0.06)$ & $0.633^{* * *}$ & $(0.05)$ & $0.228 * * *$ & $(0.06)$ \\
\hline 40-49 years & -0.015 & $(0.08)$ & $0.861^{* * *} *$ & $(0.07)$ & $0.191^{*}$ & $(0.08)$ \\
\hline $50-60$ years & $-0.698 * * *$ & $(0.08)$ & $1.128 * * *$ & $(0.07)$ & -0.005 & $(0.09)$ \\
\hline \multicolumn{7}{|c|}{ Highest Degree (Ref =No diploma or second.) } \\
\hline Short technical educ.t & $0.211^{* * *}$ & $(0.03)$ & $0.065^{*}$ & $(0.03)$ & $0.195^{* * *}$ & $(0.03)$ \\
\hline Long tech. educ.. highschool cert. & $0.320 * * *$ & $(0.03)$ & $0.120 * * *$ & $(0.04)$ & $0.416^{* * *}$ & $(0.04)$ \\
\hline Under. High. educ. & $0.497 * * *$ & $(0.04)$ & $0.181^{* * *}$ & $(0.04)$ & $0.427 * * *$ & $(0.05)$ \\
\hline Grad. High. educ. & $0.795^{* * *}$ & $(0.06)$ & $0.103^{*}$ & $(0.05)$ & $0.780^{* * *}$ & $(0.06)$ \\
\hline \multicolumn{7}{|c|}{ Labor market experience $($ Ref $=\leq 5$ years $)$} \\
\hline 6-10 years & -0.077 & $(0.08)$ & $0.248^{* * *}$ & $(0.07)$ & -0.006 & $(0.07)$ \\
\hline $11-20$ years & -0.110 & $(0.09)$ & $0.542^{* * *}$ & $(0.08)$ & -0.003 & $(0.09)$ \\
\hline$>20$ years & 0.087 & $(0.10)$ & $0.884^{* * *}$ & $(0.09)$ & 0.068 & $(0.10)$ \\
\hline \multicolumn{7}{|l|}{ Occupation $($ Ref =Clerk $)$} \\
\hline Intellectual prof. & & & & & $-0.369 * * *$ & $(0.05)$ \\
\hline Intermediate prof. & & & & & $-0.113^{* * *}$ & $(0.03)$ \\
\hline Blue collar prof. & & & & & $-0.198 * * *$ & $(0.03)$ \\
\hline Public sector & & & & & $-0.054^{*}$ & $(0.03)$ \\
\hline \multicolumn{7}{|l|}{ Activity sector $($ Ref $=$ Business $)$} \\
\hline Food. consumption ind. & & & & & -0.068 & $(0.05)$ \\
\hline Motor. equipments ind. & & & & & $-0.148^{* *}$ & $(0.05)$ \\
\hline Inter. goods ind. & & & & & $-0.178^{* * *}$ & $(0.05)$ \\
\hline Energy. construc. ind & & & & & $-0.111^{*}$ & $(0.05)$ \\
\hline Transportation & & & & & $-0.163^{* *}$ & $(0.06)$ \\
\hline Finance. real-estate & & & & & 0.002 & $(0.06)$ \\
\hline Business services & & & & & $-0.296^{* * *}$ & $(0.04)$ \\
\hline Ind. or public services & & & & & $-0.327 * * *$ & $(0.04)$ \\
\hline Administration & & & & & $-0.175^{* * *}$ & $(0.04)$ \\
\hline
\end{tabular}


Table 6: Trivariate model: Subjective downgrading, Homeownership and partial OBSERVABILITY (CONTINUED)

\begin{tabular}{|c|c|c|c|c|c|c|}
\hline & \multicolumn{2}{|c|}{$\begin{array}{l}\text { Employment } \\
\text { Coef. and s.e. }\end{array}$} & \multicolumn{2}{|c|}{$\begin{array}{l}\text { Homeownership } \\
\text { Coef. and s.e. }\end{array}$} & \multicolumn{2}{|c|}{$\begin{array}{l}\text { Downgrading } \\
\text { Coef. and s.e. }\end{array}$} \\
\hline \multicolumn{7}{|l|}{ Urban area size (Ref =rural area $)$} \\
\hline$<5000$ inhabitants & $0.098^{*}$ & $(0.05)$ & $-0.312^{* * *}$ & $(0.05)$ & 0.054 & $(0.05)$ \\
\hline$[5000-10000[$ inhabitants & 0.039 & $(0.05)$ & $-0.411^{* * *}$ & $(0.05)$ & $0.132^{* *}$ & $(0.05)$ \\
\hline$[10000-20000[$ inhabitants & $-0.153^{* * *}$ & $(0.05)$ & $-0.581 * * *$ & $(0.05)$ & -0.082 & $(0.05)$ \\
\hline$[20000-50000[$ inhabitants & $0.105^{*}$ & $(0.05)$ & $-0.429 * * *$ & $(0.05)$ & $-0.168^{* * *}$ & $(0.05)$ \\
\hline$[50000-100000[$ inhabitants & 0.032 & $(0.05)$ & $-0.327 * * *$ & $(0.05)$ & $0.164^{* * *}$ & $(0.05)$ \\
\hline$[100000-200000[$ inhabitants & $0.200 * * *$ & $(0.04)$ & $-0.504^{* * *}$ & $(0.05)$ & $0.154^{* * *}$ & $(0.04)$ \\
\hline$[100000-2000000[$ inhabitants & $0.116^{* * *}$ & $(0.03)$ & $-0.615^{* * *}$ & $(0.04)$ & $0.081^{*}$ & $(0.04)$ \\
\hline Parisian area & $0.224 * * *$ & $(0.04)$ & $-0.509 * * *$ & $(0.04)$ & $0.209 * * *$ & $(0.04)$ \\
\hline \multicolumn{7}{|c|}{ Amount of Local taxes ( $\operatorname{Ref}=<370$ euros) } \\
\hline$[370-470[$ & & & $0.150^{* * *}$ & $(0.04)$ & & \\
\hline$[470-580[$ & & & $0.279^{* * *}$ & $(0.04)$ & & \\
\hline$[580-750[$ & & & $0.290^{* * *}$ & $(0.04)$ & & \\
\hline$[750$ and +[ & & & $0.365^{* * *}$ & $(0.04)$ & & \\
\hline \multicolumn{7}{|l|}{ Year $($ Ref $=1995)$} \\
\hline 1996 & $0.454^{* * *}$ & $(0.04)$ & 0.039 & $(0.04)$ & $0.091^{*}$ & $(0.04)$ \\
\hline 1997 & $0.444^{* * *}$ & $(0.04)$ & 0.058 & $(0.04)$ & 0.078 & $(0.04)$ \\
\hline 1998 & $0.410^{* * *}$ & $(0.04)$ & 0.045 & $(0.04)$ & 0.049 & $(0.04)$ \\
\hline 1999 & $0.377^{* * *}$ & $(0.04)$ & 0.061 & $(0.04)$ & 0.037 & $(0.04)$ \\
\hline 2000 & $0.318^{* * *}$ & $(0.04)$ & 0.059 & $(0.04)$ & 0.030 & $(0.04)$ \\
\hline 2001 & $0.287 * * *$ & $(0.04)$ & 0.052 & $(0.04)$ & 0.026 & $(0.04)$ \\
\hline Constant & $1.487^{* * *}$ & $(0.09)$ & $-0.747^{* * *}$ & $(0.07)$ & $0.313^{* * *}$ & $(0.09)$ \\
\hline Correlations & $\rho_{e h}=0.113^{* * *}$ & $(0.02)$ & $\rho_{e d}=0.503^{* * *}$ & $(0.12)$ & $\rho_{h d}=0.180^{*}$ & $(0.07)$ \\
\hline$\chi^{2}$ & 2797.810 & & & & & \\
\hline Obs. nb. & 18654 & & & & & \\
\hline Log-likeli. & -26359 & & & & & \\
\hline
\end{tabular}


Table 7: Trivariate Model With unobserved heterogeneity: Subjective Downgrading, Homeownership, Partial observability and Unobserved Heterogeneity

\begin{tabular}{|c|c|c|c|c|c|c|}
\hline \multirow{2}{*}{ Homeowner } & \multicolumn{2}{|c|}{$\begin{array}{l}\text { Employment } \\
\text { Coef. and s.e. }\end{array}$} & \multicolumn{2}{|c|}{$\begin{array}{l}\text { Homeownership } \\
\text { Coef. and s.e. }\end{array}$} & \multicolumn{2}{|c|}{$\begin{array}{l}\text { Downgrading } \\
\text { Coef. and s.e. }\end{array}$} \\
\hline & & & & & -0.180 & $(0.18)$ \\
\hline Inheritance or donation & & & $0.214^{* * *}$ & $(0.05)$ & & \\
\hline Mother was inactive & $-0.070 * *$ & $(0.03)$ & & & & \\
\hline Female & $-1.143^{* * *}$ & $(0.05)$ & $0.056^{*}$ & $(0.02)$ & $-0.785^{* * *}$ & $(0.12)$ \\
\hline Foreign nationality & $-0.225^{* *}$ & $(0.08)$ & $-0.264^{* * *}$ & $(0.06)$ & $-0.445^{* * *}$ & $(0.10)$ \\
\hline \multicolumn{7}{|c|}{ Household type (Ref = Couple no child. $)$} \\
\hline Couple w. children & -0.050 & $(0.04)$ & $0.287 * * *$ & $(0.03)$ & $-0.135^{* *}$ & $(0.04)$ \\
\hline Single-parent family & $0.170^{*}$ & $(0.07)$ & $-0.739 * * *$ & $(0.06)$ & $-0.173^{*}$ & $(0.08)$ \\
\hline Single person & -0.111 & $(0.06)$ & $-0.754^{* * *}$ & $(0.05)$ & $-0.185^{*}$ & $(0.07)$ \\
\hline \multicolumn{7}{|c|}{ Spouse' status $($ Ref $=$ Employed Spouse $)$} \\
\hline Unemployed spouse & $-0.324^{* * *}$ & $(0.06)$ & $-0.444^{* * *}$ & $(0.05)$ & 0.050 & $(0.07)$ \\
\hline Inactive spouse & $-0.253^{* * *}$ & $(0.04)$ & $-0.218^{* * *}$ & $(0.04)$ & -0.006 & $(0.05)$ \\
\hline \multicolumn{7}{|l|}{ Age (Ref =17-29 years) } \\
\hline 30-39 years & 0.038 & $(0.07)$ & $0.645^{* * *}$ & $(0.05)$ & $0.209^{*}$ & $(0.08)$ \\
\hline 40-49 years & -0.081 & $(0.09)$ & $0.885^{* * *}$ & $(0.07)$ & 0.126 & $(0.10)$ \\
\hline $50-60$ years & $-1.004^{* * *}$ & $(0.11)$ & $1.165^{* * *}$ & $(0.08)$ & -0.233 & $(0.15)$ \\
\hline \multicolumn{7}{|c|}{ Highest Degree (Ref =No diploma or second.) } \\
\hline Short technical educ.t & $0.262^{* * *}$ & $(0.03)$ & $0.070^{*}$ & $(0.03)$ & $0.269 * * *$ & $(0.05)$ \\
\hline Long tech. educ.. highschool cert. & $0.413^{* * *}$ & $(0.04)$ & $0.123^{* * *}$ & $(0.04)$ & $0.555^{* * *}$ & $(0.09)$ \\
\hline Under. High. educ. & $0.627^{* * *}$ & $(0.05)$ & $0.186^{* * *}$ & $(0.04)$ & $0.582^{* * *}$ & $(0.10)$ \\
\hline Grad. High. educ. & $0.942^{* * *}$ & $(0.07)$ & $0.110^{*}$ & $(0.05)$ & $1.020^{* * *}$ & $(0.15)$ \\
\hline \multicolumn{7}{|c|}{ Labor market experience $($ Ref $=\leq 5$ years $)$} \\
\hline 6-10 years & -0.084 & $(0.09)$ & $0.250^{* * *}$ & $(0.07)$ & -0.021 & $(0.09)$ \\
\hline $11-20$ years & -0.075 & $(0.10)$ & $0.545^{* * *}$ & $(0.08)$ & -0.026 & $(0.11)$ \\
\hline$>20$ years & 0.179 & $(0.12)$ & $0.890^{* * *}$ & $(0.09)$ & 0.067 & $(0.13)$ \\
\hline \multicolumn{7}{|l|}{ Occupation $($ Ref $=$ Clerk $)$} \\
\hline Intellectual prof. & & & & & $-0.465^{* * *}$ & $(0.08)$ \\
\hline Intermediate prof. & & & & & $-0.134^{* * *}$ & $(0.04)$ \\
\hline Blue collar prof. & & & & & $-0.231^{* * *}$ & $(0.04)$ \\
\hline Public sector & & & & & -0.066 & $(0.03)$ \\
\hline \multicolumn{7}{|l|}{ Activity sector $($ Ref $=$ Business $)$} \\
\hline Food. consumption ind. & & & & & -0.100 & $(0.07)$ \\
\hline Motor. equipments ind. & & & & & $-0.194^{* *}$ & $(0.07)$ \\
\hline Inter. goods ind. & & & & & $-0.233^{* * *}$ & $(0.07)$ \\
\hline Energy. construc. ind & & & & & $-0.139^{*}$ & $(0.06)$ \\
\hline Transportation & & & & & $-0.211^{* *}$ & $(0.07)$ \\
\hline Finance. real-estate & & & & & -0.012 & $(0.07)$ \\
\hline Business services & & & & & $-0.379 * * *$ & $(0.07)$ \\
\hline Ind. or public services & & & & & $-0.425^{* * *}$ & $(0.08)$ \\
\hline Administration & & & & & $-0.237^{* * *}$ & $(0.07)$ \\
\hline
\end{tabular}

Significance: $\quad *: 10 \% \quad * *: 5 \% \quad * * *: 1 \%$. 
Table 7: Trivariate Model With UnObServed heterogeneity: SubJective Downgrading, Homeownership, Partial observability and Unobserved Heterogeneity (Continued)

\begin{tabular}{|c|c|c|c|c|c|c|}
\hline \multirow{2}{*}{ Urban area size $($ Ref $=$ rural area } & \multicolumn{2}{|c|}{$\begin{array}{l}\text { Employment } \\
\text { Coef. and s.e. }\end{array}$} & \multicolumn{2}{|c|}{$\begin{array}{l}\text { Homeownership } \\
\text { Coef. and s.e. }\end{array}$} & \multicolumn{2}{|c|}{$\begin{array}{l}\text { Downgrading } \\
\text { Coef. and s.e. }\end{array}$} \\
\hline & & & & & & \\
\hline$<5000$ inhabitants & $0.133^{*}$ & $(0.06)$ & $-0.320 * * *$ & $(0.05)$ & 0.097 & $(0.06)$ \\
\hline$[5000-10000[$ inhabitants & 0.040 & $(0.06)$ & $-0.421^{* * *}$ & $(0.05)$ & $0.193^{* *}$ & $(0.07)$ \\
\hline$[10000-20000[$ inhabitants & $-0.177^{* *}$ & $(0.06)$ & $-0.593^{* * *}$ & $(0.05)$ & -0.078 & $(0.07)$ \\
\hline$[20000-50000[$ inhabitants & $0.126^{*}$ & $(0.06)$ & $-0.436^{* * *}$ & $(0.05)$ & $-0.177^{* *}$ & $(0.06)$ \\
\hline$[50000-100000[$ inhabitants & 0.011 & $(0.06)$ & $-0.327^{* * *}$ & $(0.05)$ & $0.216^{* *}$ & $(0.07)$ \\
\hline$[100000-200000[$ inhabitants & $0.215^{* * *}$ & $(0.05)$ & $-0.506^{* * *}$ & $(0.05)$ & $0.222^{* * *}$ & $(0.06)$ \\
\hline [100000 - 2000000[ inhabitants & $0.141^{* * *}$ & $(0.04)$ & $-0.625^{* * *}$ & $(0.04)$ & $0.134^{* *}$ & $(0.05)$ \\
\hline Parisian area & $0.237^{* * *}$ & $(0.05)$ & $-0.514^{* * *}$ & $(0.05)$ & $0.288^{* * *}$ & $(0.06)$ \\
\hline \multicolumn{7}{|c|}{ Amount of Local taxes (Ref $=<370$ euros) } \\
\hline$[370-470[$ & & & $0.140^{* * *}$ & $(0.04)$ & & \\
\hline$[470-580[$ & & & $0.272^{* * *}$ & $(0.04)$ & & \\
\hline$[580-750[$ & & & $0.289 * * *$ & $(0.04)$ & & \\
\hline$[750$ and +[ & & & $0.365^{* * *}$ & $(0.04)$ & & \\
\hline \multicolumn{7}{|l|}{ Year $(\operatorname{Ref}=1995)$} \\
\hline 1996 & $0.550 * * *$ & $(0.05)$ & 0.044 & $(0.04)$ & $0.147^{*}$ & $(0.06)$ \\
\hline 1997 & $0.546^{* * *}$ & $(0.05)$ & 0.063 & $(0.04)$ & $0.130 *$ & $(0.06)$ \\
\hline 1998 & $0.506^{* * *}$ & $(0.05)$ & 0.049 & $(0.04)$ & 0.094 & $(0.06)$ \\
\hline 1999 & $0.469 * * *$ & $(0.05)$ & 0.066 & $(0.04)$ & 0.080 & $(0.06)$ \\
\hline 2000 & $0.384^{* * *}$ & $(0.05)$ & 0.065 & $(0.04)$ & 0.067 & $(0.06)$ \\
\hline 2001 & $0.346^{* * *}$ & $(0.05)$ & 0.059 & $(0.04)$ & 0.063 & $(0.06)$ \\
\hline Constant & $1.353^{* * *}$ & $(0.11)$ & $-0.644^{* * *}$ & $(0.08)$ & -0.095 & $(0.16)$ \\
\hline \multirow[t]{2}{*}{ Heterogeneity } & $\nu_{e}^{1}=1.353^{*}$ & $(0.11)$ & $\nu_{h}^{1}=-0.644^{* * *}$ & $(0.08)$ & $\nu_{d}^{1}=-0.095$ & $(0.15)$ \\
\hline & $\nu_{e}^{2}=3.303^{*}$ & $(1.34)$ & $\nu_{h}^{2}=-0.428^{* * *}$ & $(0.13)$ & $\nu_{d}^{2}=1.530^{* * *}$ & $(0.39)$ \\
\hline Proba. & $p_{1}=0.736^{* * *}$ & $(0.04)$ & $p_{2}=0.264^{* * *}$ & $(0.04)$ & & \\
\hline Correlations & $\rho_{e h}=0.305^{* * *}$ & $(0.05)$ & $\rho_{e d}=0.323$ & $(0.21)$ & $\rho_{h d}=0.270^{* *}$ & $(0.10)$ \\
\hline & 799.382 & & & & & \\
\hline Obs. nb. & 18654 & & & & & \\
\hline Log-likeli. & -26332 & & & & & \\
\hline
\end{tabular}




\section{References}

Alba-Ramirez, A. \& Blázquez, M. (2003), Type of Job Match, Overeducation and Labor Mobility in Spain, in F. Büchel, A. de Grip \& A. Mertens, eds, 'Overeducation in Europe: Current Issues in Theory and Policy', Edward Elgar Publishing, chapter 4, pp. 65-95.

Battu, H., Belfield, C. \& Sloane, P. (2000), 'How well can we measure graduate overeducation and its effects?', National Institute Economic Review 171(1), 82-93.

Battu, H., Ma, A. \& Phimister, E. (2008), 'Housing Tenure, Job Mobility and Unemployment in the UK', The Economic Journal 118(257), 311-328.

Bhaskar, V., Manning, A. \& To, T. (2002), 'Oligopsony and Monopsonistic Competition in Labor Markets', Journal of Economic Perspectives 16(2), 155-174.

Boal, W. \& Ransom, M. R. (1997), 'Monopsony in the Labor Market', Journal of Economic Literature 35(1), 86-112.

Brunet, C., Havet, N. \& Lesueur, J.-Y. (2010), 'Propriété immobilière et trajectoires salariales en France', Travail et Emploi 124, 21-30.

Brunet, C., Havet, N. \& Lesueur, J.-Y. (2011), 'La propriété immobilière est-elle un obstacle pour sortir du chômage ?', Economie et Prévision forthcoming.

Buchel, F. \& van Ham, M. (2003), 'Overeducation, regional labor markets, and spatial flexibility', Journal of Urban Economics 53(3), 482-493.

Budria, S. \& Moro-Egido, A. (2009), 'The Overeducation phenomenom in Europe', Revisita International de Sociologica 67(2), 329-345.

Cappellari, L. \& Jenkins, S. (2004), 'Modelling low income transitions', Journal of Applied Econometrics 19(5), 593-610.

Catte, P., Girouard, N., Price, R. \& André, C. (2004), 'Contribution des marchés du logement à la résilience économique', Revue Economique de l'OCDE 38(1), 139-173.

Chambaz, C. (2001), 'Les jeunes adultes en Europe : indépendance résidentielle, activité, ressources', Recherches et prévisions 65, 53-71.

Clark, A. (1997), 'Job Satisfaction and Gender: Why are women so happy at work?', Labour Economics 4(4), 341-372.

Clark, A., Couprie, H. \& Sofer, C. (2004), 'La modélisation collective de l'offre de travail : mise en perspective et application aux données britanniques', Revue Economique 55(4), 767-789.

Coulson, E. \& Fisher, L. (2002), 'Tenure Choice and Labour Market Outcomes', Housing Studies 17(1), 35-49.

David, Q., Janiak, A. \& Wasmer, E. (2010), 'Local Social Capital and Geographical Mobility', Journal of Urban Economics 68(2), 191-204.

de Graaff, T. \& van Leuvensteijn, M. (2007), 'The impact of housing market institutions on labour mobility : A European cross country comparison', CPB Discussion Paper $\mathbf{8 2}$.

de Graaff, T., van Leuvensteijn, M. \& van Ewijk, C. (2009), Homeownership, Social Renting and Labor Mobility accross Europe, in C. van Ewijk \& M. van Leuvensteijn, eds, 'Homeownership \& the Labour Market in Europe', Oxford University Press, chapter 3, pp. 53-70. 
di Paola, V. \& Moullet, S. (2009), 'Femmes et Fonction publique : un risque calculé de déclassement ?', Travail et Emploi 120, 47-61.

Di Pietro, G. (2004), 'The determinants of university dropout in Italy: a bivariate probability model with sample selection', Applied Economics Letters 11(3), 187-191.

Dietz, R. \& Haurin, D. (2003), 'The Social and Private micro-level Consequences of Homeownership', Journal of Urban Economics 54(3), 401-450.

Fondeur, Y. (1999), Le déclasssement à l'embauche, Technical report, Rapport réalisé pour le Commissariat Général au Plan.

Forgeot, G. \& Gautié, J. (1997), 'Insertion professionnelle des jeunes et processus de déclassement', Économie et Statistique 304-305(3/4), 53-74.

Garner-Moyer, H. (2003), Discrimination et emploi : revue de la littérature, Document d'étude 69, DARES.

Geweke, J., Keane, M. \& Runkle, D. (1994), 'Alternative Computational Approaches to Inference in the Multinomial Probit Model', Review of Economics and Statistics LXXXVI(4), 609-632.

Giret, J.-F. (2005), Quand les jeunes s'estiment déclassés, in J.-F. Giret, A. Lopez \& J. Rose, eds, 'Des formations pour quels emplois', La Découverte, pp. 275-288.

Giret, J.-F., Nauze-Fichet, E. \& Tomasini, M. (2006), 'Le déclassement des jeunes sur le marché du travail', Données sociales pp. 307-314.

Green, F. \& Zhu, Y. (2010), 'Overqualification, job dissatisfaction, and increasing dispersion in the returns to graduate education', Oxford Economic Papers 62(4), 740-763.

Greene, W. (2003), Econometric Analysis, 5ème édition, Prentice Hall.

Guironnet, J.-P. (2006), 'La suréducation en France : vers une dévalorisation des diplômes du supérieur ?', Economie Appliquée 59, 93-120.

Guironnet, J.-P. \& Peypoch, N. (2007), 'Human Capital Allocation and overeducation: a measure of French productivity $(1987,1999)$ ', Economic Modelling 25, 398-410.

Hartog, J. (2000), 'Over-education and earnings: where are we, where should we go?', Economics of Education Review 19(2), 131-147.

Hartog, J. \& Oosterbeek, H. (1988), 'Education, allocation and earnings in the Netherlands: Overschooling?', Economics of Education Review 7(2), 185-194.

Havet, N. \& Lacroix, G. (2003), 'Career Starts and the Male-Female Wage Gap', Cahier de la série scientifique du Cirano 2003s-55.

Havet, N. \& Penot, A. (2010), 'Does Homeownership Harm Labour Market Performances? A Survey', Working Paper - GATE Lyon Saint-Etienne 12.

Heckman, J. \& Singer, B. (1984), 'Econometric Duration Analysis', Journal of Econometrics $\mathbf{2 4}(1 / 2), 63-132$.

Hensen, M. M., de Vries, M. R. \& Cörvers, F. (2009), 'The role of geographic mobility in reducing education-job mismatches in the Netherlands', Papers in Regional Science 88(3), 667-682.

Hoynes, H. (1996), 'Welfare transfers in two-parent families: labor supply and welfare participation under AFDC-UP', Econometrica 64, 295-332. 
Johnson, W. (1978), 'The Theory of Job Shopping', Quaterly Journal of Economics 92(2), 261-278.

Jovanovic, B. (1979), 'Job Matching and the Theory of Turnover', Journal of Political Economy 87(5), 972-980.

Laferrère, A. (2005), 'Quitter le nid : entre forces centripètes et centrifuges', Economie et Statistique 381-382, 147-175.

Maddala, G. (1983), Limited Dependent and Qualitative Variables in Econometrics, Cambridge University Press.

Meng, C.-L. \& Schmidt, P. (1985), 'On the Cost of Partial Observability in Bivariate Probit Models', International Economic Review 26(1), 71-86.

Meurs, D. \& Ponthieux, S. (2000), 'Une mesure de la discrimination dans l'écart de salaire entre hommes et femmes', Économie et Statistique 337-338(7/8), 135-158.

Meurs, D. \& Ponthieux, S. (2006), 'L'écart des salaires entre les femmes et les hommes peut-il encore baisser ?', Economie et Statistique 398-399, 99-129.

Mohanty, M. (2002), 'A Bivariate Probit Approach to the Determination of Employment: A Study of Teen Employment Differentials in Los Angeles Country', Applied Economics 34(2), 143-156.

Munch, J.-R., Rosholm, M. \& Svarer, M. (2006), 'Are Home Owners Really More Unemployed ?', The Economic Journal 116(514), 991-1013.

Munch, J.-R., Rosholm, M. \& Svarer, M. (2008), 'Homeownership, Job Duration and Wages', Journal of Urban Economics 63(1), 130-145.

Nauze-Fichet, E. \& Tomasini, M. (2002), 'Diplôme et insertion sur le marché du travail : approches socioprofessionnelle et salariale du déclassement', Economie et Statistique 354, 21-48.

Nauze-Fichet, E. \& Tomasini, M. (2006), 'Parcours des jeunes à la sortie du système éducatif et déclassement salarial', Economie et Statistique 388-389, 57-83.

Oswald, A. (1996), 'A conjecture on the explanation for high unemployment in the industrialised nations: part 1', University of Warwick Economic Research Papers $\mathbf{4 7 5 .}$

Oswald, A. (1998), 'The missing piece of unemployment puzzle', CEPR Workshop on Unemployment Dynamics .

Oswald, A. (1999), The Housing Market and Europe's Unemployment: A Non-Technical Paper, unpublised paper, www2.warwick.ac.uk/fac/soc/ economics/staff/faculty/oswald/homesnt.pdf.

Poirier, D. (1980), 'Partial Observability in Bivariate Probit Models', Journal of Econometrics 12, 209-217.

Quintini, G. (2011), Over-Qualified or Under-Skilled: A Review of Existing Literature, OECD Social, Employment and Migration Working Papers 121, OECD Publishing.

Rosholm, M. \& Svarer, M. (2004), 'Endogenous wage dispersion in a search-matching model', Labour Economics 11(5), 623-645.

Rossi, P. \& Weber, E. (1996), 'The social benefits of homeownership: empirical evidence from national surveys', Housing Policy Debate 7, 1-35. 
Sicherman, N. (1991), "Overeducation" in the labor market', Journal of Labor Economics 9(2), 101-122.

Simpson, W. (1992), Urban Structure and the Labour Market: Worker Mobility, Commuting and Underemployment in Cities, Clarendon Press, Oxford.

Sloane, P. (2003), Much ado About Nothing? What does the Overeducation Literature Really Tell us?, in F. Büchel, A. de Grip \& A. Mertens, eds, 'Overeducation in Europe: Current Issues in Theory and Policy', Edward Elgar Publishing, chapter 2.

Stern, S. (2000), Simulation-Based Inference in Econometrics : Motivation and Methods, in R. Mariano, T. Schuermann \& M. Weeks, eds, 'Simulation-Based Inference in Econometrics: Methods and Applications', Cambridge, pp. 9-37.

Tanay, A. \& Audirac, P.-A. (2001), 'La difficile situation des salariés étrangers', Problèmes économiques 2695, 9-12.

Train, K. (2003), Discrete Choice Methods with Simulation, Cambridge University Press. Van de Ven, W. \& Van Praag, B. (1981), 'The Demand for Deductibles in Private Health Insurance: A Probit Model with Sample Selection', Journal of Econometrics 17, 229-252. van Leuvensteijn, M. \& Koning, P. (2004), 'The effect of home-ownership on labor mobility in the Netherlands', Journal of Urban Economics 55(3), 580-596.

van Vuuren, A. (2009), The impact of Homeownership on Unemployment in the Netherlands, in C. van Ewijk \& M. van Leuvensteijn, eds, 'Homeownership \& the Labour Market in Europe', Oxford University Press, chapter 5, pp. 113-135. 